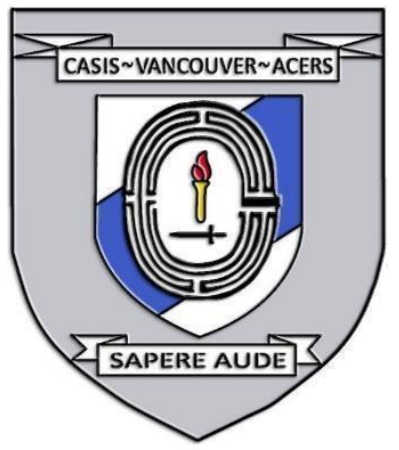

\title{
COUNTERING EXTREMIST VIOLENCE
} (CEV)

Date: November $25^{\text {th }}, 2020$

Disclaimer: This briefing note contains the encapsulation of views presented by the speaker and does not exclusively represent the views of the Canadian Association for Security and Intelligence Studies.

\section{KEY EVENTS}

On November 24, 2020, Dr. Clark McCauley presented Countering Extremist Violence $(C E V)$ at the 2020 CASIS West Coast Security Conference. The presentation was followed by a group panel for questions and answers. Main discussion topics included the distinction between terrorists and extremists; extremist violence; the role of Islam in extremism; and deradicalization.

\section{NATURE OF DISCUSSION}

\section{Presentation}

Dr. McCauley discussed the distinction between terrorists and extremists. While an extremist idea in itself is not inherently problematic, it becomes problematic when an extremist idea is combined with violence. Thus, the discussion of extremism should be focused on the violence component, rather than the extremist part to avoid diverting attention to the issue of freedom of speech.

\section{BACKGROUND}

\section{Presentation}

The presentation began with the ethical stance of acts committed by Jihadists. While the West refers to these as acts of terrorism, violent Muslim activists are defend the attacks as they regard them to be just and sanctified; therefore, violent Muslim extremists believe it is the duty of good Muslims to support these actions.

Dr. McCauley referred to his October 2016 survey and pointed out that polling data shows that a lot of people believe that US foreign policy is dictated by Jewish interests; $47 \%$ of Muslims polled in this study agreed with this kind of Muslim grievance and thus sympathize with Jihadist justifications for the use of violence. The survey revealed that American Muslims felt they were discriminated against 
by US foreign policy in the Middle East. They believed they were not real Americans but Muslims, and if they are Muslims, then they should care about Muslims all over the world. This belief fuels the identification with the Ummah (Arabic for community), which registered as a grievance regarding the US foreign policy in relation to the Ummah.

After outlining the origin of Muslim grievances, Dr. McCauley argued that violent extremists believe only violence can achieve change, and so a decline in sympathy for terrorist grievances could lead to a decline in terrorist attacks. He also made the point that having a grievance is not the same as turning to violence. Dr. McCauley postulated that the recognition of grievances is the best way to fight terrorism as a reduction in terrorist sympathy reduces terrorist attacks.

Deradicalization is the process of reducing one's sympathy for terrorist grievances. Instead of writing off or suppressing Muslim grievances, the authorities working on deradicalization should focus on recognizing Muslim grievances and establishing a common ground to facilitate discussions to resolve them.

\section{KEY POINTS OF DISCUSSION}

- It is important to distinguish between terrorists and extremists.

- There are two sources of American Muslims perceiving a war on Islam: discrimination at home and US foreign policy abroad.

- Religion was a key component but not the head of burning urge to spread Islam and to establish caliphates. It was a desire to protect religion against what was commonly seen to be a concentrated war in the Middle East by the US government and the military.

- The process of deradicalizing violent extremists depends on acknowledging, or at least recognizing, the grievances Muslims have against Western foreign policy in the Middle East as well as perceived discrimination at home.

- Violent extremists believe only violence can achieve change, and so a decline in sympathy for terrorist grievances could lead to a decline in terrorist attacks. Acknowledging Muslim grievances is one way to reduce sympathy for Muslim terrorists. 


\section{(ब) $8 \Theta$}

EY NC ND This work is licensed under a Creative Commons Attribution-

NonCommercial-NoDerivatives 4.0 International License.

(C) (Clark McCauley, 2021)

Published by the Journal of Intelligence, Conflict, and Warfare and Simon Fraser University

Available from: https://jicw.org/ 